\title{
MICROBIAL CONCENTRATION OF AMBIENT AIR IN POLY-CLINIC ROOM AT COMMUNITY HEALTH CENTER, KENDARI, SOUTH EAST SULAWESI
}

\author{
Putri Alam, Ellfi, Eka Dharma Putra Marhanto
}

Masters Program in Public Health, School of Health Sciences Mandala Waluya, Kendari

\begin{abstract}
Background: The risk of nosocomial infection is increasing due to the increasing number of patients with immune depression. Good ventilation is one of the methods used to reduce the ambient air levels of the causative agents. This study tested the microbiological air quality at different areas of the Poasia community health center, Kendari, South East Sulawesi to ascertain the levels of airborne bacteria in the ambient air.

Subjects and Method: A cross sectional study was carried out at Poasia community health center, Kendari, South East Sulawesi. Seven rooms of the community health center were selected for this study including waiting room, laboratory, dental clinic, delivery room, general poly, treatment room, and kitchen. The dependent variable was existence the bacteria. The assessment was carried out by exposing petri dishes containing the appropriate culture media for about $30 \mathrm{~min}$ at a convenient place in each of the seven study sites. Thereafter, the plates were covered and immediately transferred to the laboratory for incubation at $37^{\circ} \mathrm{C}$, for $24-48 \mathrm{~h}$. The numbers of bacteria in the cultures were determined at the end of the incubation period

Results: Bacteria were detectable in the ambient air of all study sites. On Monday the highest level of microbia $74 \%$ was in the waiting room, and the lowest level $17 \%$ in the laboratory. On Tuesday the highest level was in the laboratory, and the lowest level 22\% in the dental clinic. On Wednesday the highest level was $160 \%$ in laboratory, and the lowest level 19\% in the maternity room. On Thursday the highest level was $110 \%$ in the laboratory, the lowest level was $19 \%$ in the maternity room. On Friday the highest level was $100 \%$ in the laboratory, and the lowest level was $25 \%$ in general poly, dental polyclinic, and treatment room. On Saturday the highest level was $120 \%$ in the laboratory, the lowest level was $13 \%$ at the dentist clinic.

Conclusion: The indoor air of Poasia community health center were in the below of the range according to Decree of the Minister of Health of Indonesia No. 1204/ MENKES/ SK/ X/ 2004. However airborne bacteria in the ambient air often associated with clinical manifestations like allergy, rhinitis, asthma and conjunctivitis. Thus, attention must be given to control those environmental factors which favor the growth and multiplication of microbes in indoor environment to safeguard the health of users and workers.
\end{abstract}

Keywords: microbia concentration, air borne, ambient air.

\section{Correspondence:}

Putri Alam. Masters Program in Public Health, School of Health Sciences Mandala Waluya, Jl. A.H.Nasution No. G 37, Kendari, South East Sulawesi. Email: putrialamskm@yahoo.com.

The $5^{\text {th }}$ International Conference on Public Health Best Western Premier Hotel, Solo, Indonesia, February 13-14, 2019 | 112 https://doi.org/10.26911/theicph.2019.01.29 